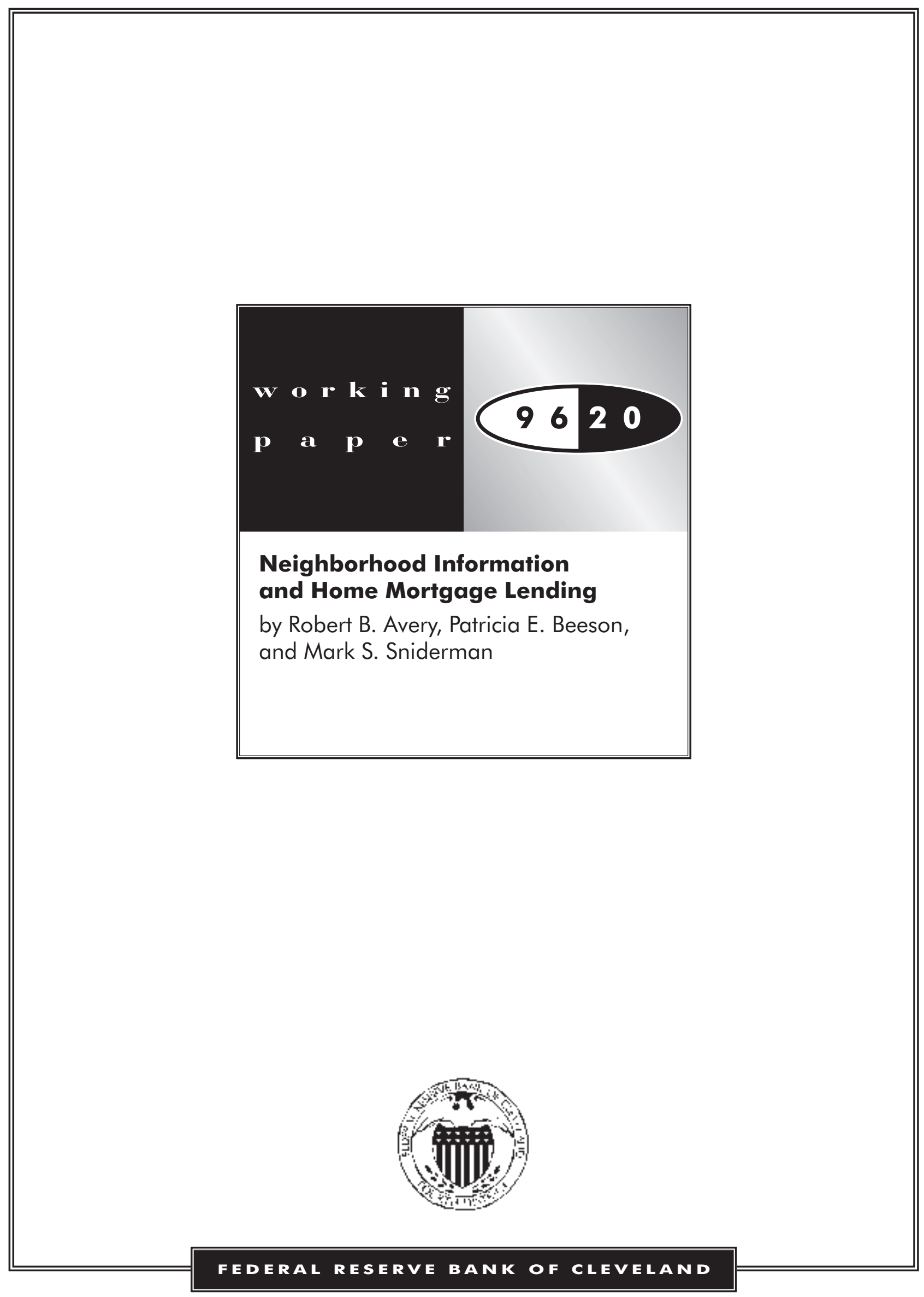




\title{
Neighborhood Information and Home Mortgage Lending
}

\author{
by Robert B. Avery \\ Cornell University and the Board of Governors of the Federal Reserve System \\ Patricia E. Beeson \\ University of Pittsburgh and the Federal Reserve Bank of Cleveland \\ Mark S. Sniderman \\ Federal Reserve Bank of Cleveland
}

November 1996

Not for quotation or publication without the authors' permission. The views stated herein are those of the authors and not necessarily those of the Federal Reserve Bank of Cleveland or of the Board of Governors of the Federal Reserve System. 


\begin{abstract}
In this paper, we empirically examine how information about a neighborhood affects the level of lending activity in it. Specifically, do lenders deny mortgage applications at higher rates in neighborhoods where they have little experience in evaluating applications, and/or in neighborhoods where the lending community in general has little experience? The analysis uses data collected under the Home Mortgage Disclosure Act (HMDA) for 1990 and 1991 to construct denial rates for each lender in each census tract, controlling for applicant characteristics observed in the HMDA data. We then estimate the relationship between these lender-tract denial rates and both the number of applications processed by the lender in that neighborhood and the number of applications processed by all lenders in that neighborhood, controlling for other characteristics of the census tract and for the lender.

We find that the more applications a lender processes from a given neighborhood, the lower the neighborhood-lender denial rates -- both statistically and economically. Furthermore, we find that the low number of applications taken by individual lenders from specific low-income and minority neighborhoods does contribute to the relatively high denial rates in these neighborhoods. These findings are consistent with recent theoretical models linking redlining to incomplete information.
\end{abstract}


Congress enacted the Community Reinvestment Act of 1977 (CRA) to combat redlining, an alleged practice in which lenders curtail the supply of mortgage credit to particular neighborhoods, discounting the creditworthiness of the applicants because the neighborhood itself is considered undesirable. Under the CRA's provisions, regulators are to use their supervisory authority to encourage each depository institution to help meet the credit needs of their communities -- including low- and moderate-income neighborhoods -- consistent with safe and sound lending practices.

Property location clearly affects mortgage credit flows and approval rates. ${ }^{1}$ Lenders worry that houses located in neighborhoods containing some dilapidated and vacant properties, low rates of owner-occupied units, and low rates of property turnover expose their collateral to price depreciation. Obviously, lenders have an incentive to acquire information about the neighborhoods in their service areas, just as they do regarding information about applicants' ability to repay loans. Information about applicants and neighborhoods is expensive to collect and process, so lenders also face incentives to collect only the amount and type of information that leads to efficient lending decisions. Numerous studies have examined the use of race as an information variable for credit market decisions. ${ }^{2}$

1 See Barth, Cordes, and Yezer (1979), Benston (1981), Canner (1981), Avery and Buynak (1981), Bradbury, Case, and Dunham (1989), and Avery, Beeson, and Sniderman (1994).

2 See Canner, Gabriel, and Wooley (1991), Gabriel and Rosenthal (1991), and Duca and Rosenthal (1992) as recent examples of research explicitly examining loan-market imperfections. 
Economists have long recognized that information imperfections in credit markets can generate divergent outcomes for borrowers of different types. ${ }^{3}$ Recent papers by Lang and Nakamura (1993) and Gruben, Neuberger, and Schmidt (1990) present theoretical models of redlining based on incomplete information. In this paper, we empirically examine how information about a neighborhood affects the level of lending activity in it. In doing so, we touch on two aspects of the debate concerning the CRA. First, does the overall goal of increasing lending in low- and moderate-income neighborhoods improve the efficiency of the mortgage market? Second, is the current requirement that each individual lender be active in these neighborhoods the most efficient method of achieving the goal of increasing aggregate lending?

Both Lang and Nakamura, and Gruben, Neuberger, and Schmidt argue that since lenders receive few applications from low- and moderate-income neighborhoods, they have little information about how to evaluate the applications. Therefore, they tend to deny them more often than they do applications from higher-income neighborhoods, where the lending market is more active. While both papers focus on the role of information, they differ in the way they model the information. As a result of this difference, the models have different implications for the efficient design and enforcement of the CRA.

In Lang and Nakamura, information is a public good: As one lender increases lending in a neighborhood, it generates information that is beneficial to all potential

\footnotetext{
3 See Stiglitz and Weiss $(1981,1987)$ for descriptions of the standard models.
} 
lenders there. For example, the authors argue that each transaction generates information on the value of houses in the neighborhood that all lenders can use in their property appraisals. As the number of transactions increases, appraisals become more precise, reducing lender uncertainty about house values. Since borrowers can default when a property is overvalued but lenders do not share in gains when a house is undervalued, greater uncertainty will lead lenders to deny more applications.

Since all lenders can use information from each transaction in their appraisals, this is a classic externality problem. Because lenders do not capture the full value of the information contained in their transactions, they will underinvest in neighborhood information, and the number of loans made in neighborhoods with few loan applications will be suboptimal. We refer to this as the external effect of information. By encouraging lending activity in these neighborhoods, the CRA increases efficiency in the lending market. Furthermore, it doesn't matter if all lenders increase lending or if just a few do, because the information generated by the transaction is available to all lenders. Therefore, according to Lang and Nakamura's model, the CRA's requirement that all lenders be active in these neighborhoods could be an efficient means of increasing lending.

In Gruben, Neuberger, and Schmidt (1990) the information generated by the transaction is a private good, accruing only to the lender actually engaged in the transaction. ${ }^{4}$ We refer to this as the internal effect of information. As lenders increase

\footnotetext{
${ }^{4}$ In a more general formulation, one could consider other fixed costs of neighborhood lending, such as an office.
} 
their activity in a neighborhood, they gain information that they can use in processing subsequent applications for properties in the same neighborhood, lowering per-unit processing costs. If lenders cannot differentially price across neighborhoods, they will tend to reject more applications in neighborhoods where per-unit costs are higher (that is, neighborhoods from which they receive few applications), than in neighborhoods where they are more active.

This is a case of increasing returns to scale that are internal to the firm, where the per-unit cost of information falls as the number of applications processed by an individual lender increases. Thus, in neighborhoods where demand is relatively low, per-unit costs will be lower when fewer lenders are active in the market. This suggests that by encouraging all lenders to be active in all neighborhoods, the CRA may be increasing the costs of lending in neighborhoods with thin demand. ${ }^{5}$

Calem (1996) provides some empirical support for these models. He finds lower denial rates in communities with thicker markets, that is, more home sales. While this may be interpreted as evidence of the external effects of information discussed in Lang and Nakamura, it probably captures both the external and internal effects, since total home sales are likely to affect each individual lender's ability to exploit internal economies of scale, as well as the amount of information available to all lenders in the neighborhood.

${ }^{5}$ Limiting the number of lenders in an area may also reduce efficiency if these lenders are able to exploit monopoly power and limit the number of loans to the neighborhood. The potential gains in efficiency from having few lenders in an area must be weighed against this potential loss. 
In this paper, we empirically test both of these perspectives on information's role, using national home mortgage lending and neighborhood information. For each lender in our sample we construct application denial rates specific to each neighborhood in which it operates, controlling as best we can for the applicants' individual characteristics. We then investigate how the cross-sectional variation in these lenderneighborhood-specific denial rates is related to a set of neighborhood demographic variables, plus the volume of applications received by the lender in that neighborhood (capturing the internal effects of information) and the volume of applications received by all lenders taking applications in that neighborhood (capturing the external effects of information).

We then address the impact of this information on neighborhood lending. For each neighborhood we sum the external and internal effects of information for the individual lenders, in order to construct measures for each neighborhood. We then array neighborhoods according to their median family income and percent minority population to see whether the information effects contribute to differences in denial rates across neighborhoods, consistent with the theoretical models.

We find convincing support for the internal information effect that Gruben, Neuberger, and Schmidt advance. The more applications a lender processes from a given neighborhood, the lower the neighborhood-lender denial rates -- both statistically and economically. Furthermore, the low number of applications taken by individual lenders from specific low-income and minority neighborhoods does contribute to the 
relatively high denial rates in these neighborhoods. We do not find evidence supporting the external information effect advanced by Lang and Nakamura.

This suggests that, based strictly on information dynamics, the CRA may inhibit lending to the most underserved neighborhoods, which have relatively few real estate transactions. The CRA's requirement that all lenders be active may hinder many of them from getting the critical mass of applications they need to obtain information about the neighborhood and its residents at a lower cost. Policies that encourage neighborhood specialization on the part of lenders may be preferable to policies that force all lenders to act the same.

\section{EMPIRICAL FRAMEWORK}

This paper examines the relationship between the percentage of mortgage loan applications denied by each lender in a neighborhood (census tract) and the neighborhood lending activity of both the lender and the market as a whole. Our analysis employs a two-stage estimation procedure to control for other applicant, lender, and neighborhood characteristics that may affect the denial rate of an individual lender. In the first stage, we use home mortgage application data for 1990 and 1991, collected under the 1989 revisions to the Home Mortgage Disclosure Act (HMDA), to identify and control for as many borrower and loan characteristics as the limited information in HMDA permits. We also include dummy variables (fixed effects) for each lenderneighborhood combination. In the second stage, the lender-neighborhood fixed effects 
from the first stage are regressed against measures of neighborhood lending activity of both the lender and neighborhood, along with controls for other lender and neighborhood characteristics.

In the first stage, we fit a model of the following form: ${ }^{6}$

(1) DENY $_{i L T}=\beta_{\mathrm{A}} \mathrm{AC}_{\mathrm{i}}+\beta_{\mathrm{LT}} \mathrm{LENDERTRACT}_{\mathrm{LT}}+\beta_{\mathrm{M}} \mathrm{MSA}_{\mathrm{M}}+\mathrm{e}_{\mathrm{iLT}}$,

where DENY ${ }_{\mathrm{iLT}}$ is one if the ith application using the Lth lender for a property in the Tth census tract is denied, and zero otherwise. $\mathrm{AC}_{\mathrm{i}}$ is a vector of application characteristics reported in the HMDA data. It includes race, gender, marital status, occupancy, income, loan amount, income-to-loan ratio, federal loan guarantee (Federal Housing Administration [FHA] or Department of Veterans Affairs [VA]), and the month of the year the application was acted upon. LENDERTRACT $\mathrm{LT}_{\mathrm{LT}}$ is a set of dummy variables indicating the lender-tract combination for each application, $\mathrm{MSA}_{\mathrm{M}}$ is a set of dummy variables indicating the metropolitan statistical area (MSA), and $\mathrm{e}_{\mathrm{iLTi}}$ is a residual. The model is specified and estimated separately for each of the two sample years, 1990 and 1991. We employ a linear probability specification, mainly because of the size of the data set. However, this is an arbitrary specification.

To help minimize the possibility that the differences we identify within and across neighborhoods reflect nonlinearities in other effects that are correlated with location, we allow for a considerable degree of nonlinearity in the effects of individual characteristics. Race is entered as a set of dummy variables indicating the race of the 
applicant and coapplicant; each is interacted with FHA/VA status as well as income. Income and loan amount are entered as linear spline functions with seven knots each, and the income-to-loan ratio is entered as a series of six dummy variables. A five-knot spline for income is interacted with a dummy variable indicating the presence of a coapplicant, and with dummy variables indicating that the application is for an FHA or VA loan. Similarly, a five-knot linear spline of loan amount, and the six dummy variables indicating ranges of values for the ratio of income to loan amount, are also interacted with a dummy variable indicating applications for FHA or VA loans.

In the second stage, we estimate the following model:

(2) $\operatorname{ADJDENY}_{\mathrm{LT}}=\beta_{1} \mathrm{APPS}_{\mathrm{LT}}+\beta_{2} \mathrm{APPS}_{\mathrm{T}}+\beta_{\mathrm{L}} \mathrm{LENDER}_{\mathrm{L}}+\beta_{\mathrm{T}} \mathrm{CENSUS}_{\mathrm{T}}+\mathrm{u}_{\mathrm{LT}}$. The dependent variable, ADJDENY $_{\mathrm{LT}}$, is computed directly from the first-stage results, as the average of the 1990 and 1991 fixed effects for each lender-tract combination, and is constructed to have a mean of zero across all lender-tract combinations in the full HMDA sample. This dependent variable can be thought of as the denial rate for lender $\mathrm{L}$, in tract $\mathrm{T}$, adjusted for applicant and MSA characteristics.

$\mathrm{APPS}_{\mathrm{LT}}$ and APPS ${ }_{\text {. }}$ are the total number of applications for properties in tract $\mathrm{T}$ received by lender $\mathrm{L}$, and received by all lenders, respectively. We use these variables to examine the internal and external effects of information on neighborhood lending by individual lenders. If there are economies of scale in neighborhood lending that are internal to the lender, then neighborhood denial rates will be lower for those lenders

\footnotetext{
${ }^{6}$ A detailed description of the first-stage estimation and the data used in the analysis
} 
with a large presence in the neighborhood, and the coefficient on $\mathrm{APPS}_{\mathrm{LT}}$ will be negative. On the other hand, if there are externalities in neighborhood lending then denial rates for all lenders will be lower in high- application neighborhoods, independent of the number of applications received by the individual lender, as all lenders benefit from the information generated by higher levels of activity. In this case, we expect the coefficient on APPS $_{\text {T }}$ to be negative.

A vector of tract characteristics drawn from the 1980 and 1990 Decennial Censuses $\left(\right.$ CENSUS $\left._{\mathrm{T}}\right)$ is included to control for other neighborhood characteristics that may affect denial rates in the tract. Specific variables included in CENSUS $_{T}$ are: 1) percent minority population of each tract, defined here as Hispanic, black, Asian, native American, and other race, 2) median family income, 3) median owner-occupied house value, 4) age distribution of household heads, 5) distribution of residential dwellings by number of units in the structure, 6) percentage of one-to-four-unit residential properties that were vacant and rented, and 7) variables indicating the distribution of the housing stock by age. We used 1990 values for each of these variables (except the housing age variables, which used 1980 data), as well as for the change from 1980 to 1990 . To control for characteristics of lenders that may affect the rate at which they deny applications in all neighborhoods, we include a set of dummy variables representing each lender $\left(\mathrm{LENDER}_{\mathrm{L}}\right)$. As in the first stage, the estimation allows for a considerable degree of nonlinearity.

can be found in Avery, Beeson, and Sniderman (1994). 


\section{DATA}

\section{Mortgage Loan Application and Disposition Data}

Data on individual loan applications and dispositions for 1990 and 1991, used in the first-stage estimation for the denial rate and to calculate $\mathrm{APPS}_{\mathrm{LT}}$ and $\mathrm{APPS}_{\mathrm{T}}$ in the second stage, are collected under the 1989 revisions to HMDA. The amended HMDA data form one of the most comprehensive sets of statistics on mortgage lending available in the United States. ${ }^{7}$ Nearly all commercial banks, savings and loan associations, credit unions, and other mortgage lending institutions (primarily mortgage banks) with assets of more than $\$ 10$ million and an office in an MSA are required to report on each mortgage loan purchased and loan application filed during the calendar year. Lenders must report the loan amount, census tract of the property, whether the property is owner-occupied, the purpose of the loan (home purchase, home improvement, or refinancing), loan guarantee (conventional, FHA, or VA), loan disposition (loan approved and originated, application approved but withdrawn, no lender action taken because the data were incomplete or the application was withdrawn, or application denied), race and gender of the loan applicant (and coapplicant, if any), and income relied on by the lending institution in making the loan decision. ${ }^{8,9}$

\footnotetext{
7 While the HMDA data are the most comprehensive data available on mortgage lending, they are still limited in the information they provide concerning each application. In particular, credit history and down-payment information are not reported.

${ }^{8}$ See Canner and Smith $(1991,1992)$ for a comprehensive discussion of the HMDA data.
} 
In total, 9,333 financial institutions filed HMDA reports for 1990 on 6,595,089

loans. In 1991, 9,365 institutions filed on 7,939,107 loans. In the first-stage analysis, we use the 4,072,158 loan applications for the purchase of one-to-four-unit residential properties that were acted upon (denied or accepted) by lenders in the two years. ${ }^{10,11}$ These applications were received by 8,745 separate institutions operating in 40,008 census tracts in all 341 of the MSAs defined as of 1990. For our analysis, we define

${ }^{9}$ Institutions with assets of less than $\$ 30$ million are not required to report race, income, or gender for loan applicants. In addition, the HMDA filings contain many errors and inconsistencies, even after extensive editing by the receiving agencies. We dealt with missing and implausible data by using a "hot deck" imputation procedure similar to that used by the U.S. Census Bureau. Applications with missing or implausible data were statistically matched to applications for the same type of loan in the same census tract that came closest to them in reported characteristics (race, loan action, income, and loan amount). Missing values were filled in using the variable value of the matched observation. Overall, income was imputed for 4.9 percent, loan amount for 1.5 percent, gender for 4.0 percent, and race for 5.6 percent of the study sample applications.

10 The following loan filings were omitted from the sample: 1) loans purchased from other institutions (because they did not require an action by the reporting lender and often were missing geographic information) and applications for properties outside the MSAs in which the lender had an office (5,670,768 applications dropped), 2) refinancing (2,216,810 dropped) or home improvement loan applications (1,649,470 dropped) 3 ) applications for multifamily homes (55,703 dropped), and 4) applications that never reached the stage of lender action because they were either withdrawn by the applicant or closed for incompleteness $(869,287$ dropped). The final sample includes some mobile home loans and condominium loans, since they were treated as one-to-four-family units in the HMDA reporting guidelines.

11 The distinction between loan types may be blurred. Institutions were allowed to report home improvement loans secured by a first lien as either home purchase or home improvement loans. Some home improvement loans may also be reported as refinancings if a new first lien was issued. Some refinancing may not have been reported at all. If a refinancing was undertaken primarily for a purpose other than home purchase or home improvement (such as college expenses or to start a business), then it did not have to be reported. Similarly, unless the borrower specifically noted home improvement as a reason for the loan, lenders did not have to report home equity or second-lien mortgages. 
lender at the MSA level; thus, an institution reporting applications for two different MSAs is treated as two different lenders. There are 23,248 such lenders in the sample used to estimate equation (1).

Table 1 presents descriptive statistics for the applications reported for 1990 and 1991 under HMDA. Clearly, housing credit applicants are a select group of American families. Applicants' median income $(\$ 48,000)$ is substantially higher than that of all families in MSAs $(\$ 37,918)$ as reported in the 1990 Decennial Census. ${ }^{12}$ It is also apparent that application and denial rates differ substantially by race and by income of applicants.

12 In the HMDA data, household income may be slightly understated, as it reflects only the portion of an applicant's income needed for mortgage qualification. 


\section{Census Data}

Data drawn from the 1980 and 1990 Decennial Censuses are used to construct many of the explanatory variables in the second stage of the analysis. In filing 1990 and 1991 HMDA reports, lenders were required to use 1980 census tract definitions. However, the Census Bureau reports the most relevant census information, that for 1990, using 1990 tract definitions. Unfortunately, although most tracts remained the same, some boundary definitions changed between 1980 and 1990. To resolve this problem, we decided to use 1980 tract definitions as the mode of analysis and to use estimates of 1990 census information. We obtained data from Claritas Corporation, which aggregated block-level 1990 census data to 1980-defined tract totals. Change variables are calculated using 1980 census information and Claritas' 1990 estimates.

Census tracts are dropped from the sample for several reasons. The census and HMDA data could not be aligned for a few outer areas of some MSAs that were not tracted in 1980, so our sample does not include them. We lack census information on Puerto Rico and thus exclude it from the analysis. We also drop tracts that had no residents, those with insufficient numbers to provide racial breakdowns, and those with less than 50 dwellings. We also require that each lender-tract combination used in the second stage have loan applications in 1990 and 1991, to control for potential bias in HMDA reporting.

The net effect of these restrictions is to reduce the number of lender-tract combinations used in the second-stage estimation to 278,808 , less than one-third the 
number in the original sample. The second-stage sample represents 36,008 of the original 40,008 census tracts, 12,234 of the original 23,248 MSA lenders, and $2,456,834$ of the original 4,072,158 loan applications. The major cause of the sample reduction is the loss of those lender-tract combinations where the lender reported applications in only one of the two years. Either the lender did not report under HMDA one of the two years, or a reporting lender received an application for a property in the tract only one of the two years.

The sample distribution of tracts, one-to-four-family housing units, loan applications, and denial rates are reported in table 2, including information for the total population and for minorities. This table shows distributions for census tracts sorted by minority population share in 1990, change in minority population share from 1980 to 1990, share of black population, share of Hispanic population, median owner-occupied housing value in 1990, percentage change in median housing value from 1980 to $1990,{ }^{13}$ median family income in 1990 , and center city/suburban and MSA size.

The most interesting comparison in table 2 is between column 2 (the stock of one-to-four-unit residential properties) and columns 3 and 4 (loan applications for comparable units). Tracts with less than 5 percent minority population are proportionately represented in loan applications, whereas tracts with 10 percent to 50 percent minority populations have disproportionately more loan applicants, and those with more than 50 percent minority populations have disproportionately fewer

${ }^{13}$ Measured in nominal terms. The Consumer Price Index rose about 50 percent over this period. 
applicants. Predominantly black tracts seem to be particularly underrepresented. It also appears that tracts with median family incomes below $\$ 40,000$ have a disproportionately small number of applicants. These differences related to neighborhood characteristics are consistent with those related to characteristics of the individual applicants discussed earlier.

\section{ESTIMATION AND RESULTS}

Parameter estimates for the first-stage regressions predicting the denial of an application are presented in table 3. ${ }^{14,15}$ When examining these numbers, one can interpret a positive coefficient as the expected increase in the probability that an applicant's loan will be denied as a result of a one-unit increase in the independent variable, holding all other variables constant (specifically, the applicant's MSA, census tract, and lender). Thus, the coefficients on race, for example, represent the expected difference in the probability that a white and black applicant with the same income, gender, FHA/VA status, loan amount, month of action date, MSA, census tract, and lender will be refused a loan. Thus interpreted, the estimated black/white (.104 and

14 The model was actually estimated using deviations about the lender-tract means, a method which is computationally equivalent to a single-component fixed-effects model. For 1990 (1991), the home purchase sample had 1,984,688 $(2,087,470)$ observations located in $607,631(662,571)$ unique combinations of 40,008 $(39,963)$ tracts and 20,695 $(26,508)$ lenders spread across 340 (341) MSAs; thus, the average tract had about 15 lenders in each year, each of which served about 30 tracts per MSA.

15 The reported standard errors in table 3 are those from a standard regression program. They may be biased due to heteroskedasticity stemming from the linear-probability-model specification. 
$.106)$ and Hispanic/white (.038 and .052) differences for conventional home purchase loans are quite significant. Similarly, the differences by applicant's income are also quite large, particularly for the lowest-income applicants. The estimates in table 3 indicate that, for all racial groups, the expected probability that an application will be denied decreases almost 1 percentage point per $\$ 1,000$ income up to an income of $\$ 20,000$, and 0.3 percentage points per $\$ 1,000$ from $\$ 20,000$ to $\$ 40,000$; this implies a difference of 10 percentage points between applicants with $\$ 10,000$ of income and those with $\$ 20,000$. Since U.S. neighborhoods tend to be differentiated by income and race, these differences in the probability of denial related to the applicant's race and income contribute to the observed differences across neighborhoods.

Parameter estimates for total applications for properties in a tract $\left(\mathrm{APP}_{\mathrm{LT}}\right)$ and total applications received by the individual lender ( $\left.\mathrm{APP}_{. \mathrm{T}}\right)$ from the second-stage regressions are presented in tables 4 and $5 .{ }^{16}$ Parameter estimates for other variables are reported in Appendix table 1. All models are estimated using ordinary least squares.

Table 4 presents the results for our basic model, in which APPS $_{\mathrm{LT}}$ and $\mathrm{APPS}_{\text {.T }}$ are entered as series of dummy variables to allow for possible nonlinearities. The coefficients on $\mathrm{APPS}_{\mathrm{LT}}$ indicate that denial rates are significantly lower for lenders that process more applications from the neighborhood, controlling for the total number of applications processed for the neighborhood, other tract characteristics, the applicant

\footnotetext{
16 All models are estimated using ordinary least squares. The reported regressions give equal weight to each lender-tract combination. In unreported regressions, each model is estimated giving equal weight to each tract, and giving equal weight to each application. The estimates are robust to these alternative weightings.
} 
characteristics included in the first-stage estimation, the lender, and the MSA. In addition to being statistically significant, the estimated effects are quite large. The predicted denial rate for a lender that processes 30 or more applications for properties in a given tract is 3.1 percentage points lower than an otherwise identical lender processing less than 3 applications from the tract. There apparently is no consistent pattern to the coefficients estimating the relationship between an individual lender's denial rate and the total number of applications processed by all lenders, although an Ftest rejects the hypothesis of no relationship $(\mathrm{F}=2.78)$.

An alternative specification of the model is estimated with APPS $_{\mathrm{LT}}$ and $\mathrm{APPS}_{\mathrm{T}}$ entered linearly, rather than as a series of dummy variables. While this specification is more restrictive, it produces a summary measure of the underlying relationship that is not apparent in the dummy variable specification. The estimated coefficients for $\mathrm{APPS}_{\mathrm{LT}}$ and APPS $\mathrm{T}_{\mathrm{T}}$ are reported as model 2 in table 4. They indicate that denial rates decline as the number of applications processed by the individual lender increases, and increase as the total number of applications in the tract increases. Both estimated coefficients are significantly different from zero at the 1 percent level of confidence.

In the above estimation, we assume that census tracts represent homogeneous neighborhoods and therefore estimate the models based on the number of applications in a tract. While this criterion is used to define census tract, in practice this may not be the case. Since neighborhoods tend to shift over time, this mismatch is likely to be large in our data because the loan application data were collected 10 years after the 
1980 census tracts were constructed. As a result, the 1980 census tract definitions may over- or underestimate the size of neighborhoods in 1990. We attempt to overcome this mismatch by estimating a model in which each lender's share of total applications in the tract and total applications per one-to-four-family housing unit in the tract are substituted for $\mathrm{APPS}_{\mathrm{LT}}$ and APPS.T. The coefficient estimates for $\mathrm{APPS}_{\mathrm{LT}}$ and $\mathrm{APPS}_{\mathrm{T}}$, entered as series of dummy variables and entered linearly, are reported in table 5, as models 3 and 4, respectively. These estimates are generally consistent with those reported above. Lenders' denial rates decline significantly as their share of the market increases, and the elasticity is comparable to estimates for $\mathrm{APPS}_{\mathrm{LT}}$ in the basic model (table 4). In addition, while the estimated coefficient on applications per housing unit is negative, the elasticity is small and we cannot reject the hypothesis of no relationship at the 10 percent level.

We also estimate all four models separately for minority and white applicants. For both groups we find that denial rates decline as the number of applications processed by the individual lender increases, and increase as the total number of applications in the tract increases. There is little differences in coefficient estimates across the two groups of applicants.

Thus, in all specifications we find that a lender's neighborhood denial rate declines as the lender processes more applications from the neighborhood. This finding is consistent with internal economies of scale in neighborhood lending related to private information. We do not find any evidence of positive externalities related to 
information in neighborhood lending. If anything, increases in applications processed by other neighborhood lenders slightly increase the denial rate of a given lender, holding constant the number of applications processed by that individual lender, suggesting negative externalities.

There are several alternative explanations of our results. Some lenders enter into agreements with developers where the lender agrees to provide financing and the developer effectively "prescreens" applicants for the lender. Thus, a lender may receive a large number of applications from a given tract, and have a low denial rate on applications from the tract, but the low denial rate would have nothing to do with information gained from processing applications. We have no data on these partnerships, but since these large developments are more likely in suburban than in central city neighborhoods, we estimated all models separately for central cities and for suburbs. Our results do not differ substantially between the two geographic areas.

Alternatively, it may be that low denial rates are attracting large numbers of applicants, rather than large numbers of applications leading to lower denial rates, as we are assuming. Two considerations work against this interpretation. First, we include a dummy variable for each lender that will control for systematic differences across lenders. So, it would have to be that for some the lender has a lower denial rate in one tract than in others, and that this attracts more applications only for properties in that tract. Second, marginal applicants more likely than others to be influenced by 
considerations such as which lender has the lowest denial rate, and this would tend to increase the denial rates for these lenders.

Another possibility is that people may believe, correctly or not, that the large lender in their neighborhood has access to more and better information when processing loan applications, and as a result, these lenders attract not only more applicants but also more creditworthy ones, and therefore have lower denial rates. If large lenders are also low-rate lenders, this is consistent with Avery, Beeson, and Sniderman's (1995) finding that lenders advertising low interest rates tend to attract more creditworthy applicants and have lower denial rates than lenders advertising high rates. For this to explain our results, a lender's reputation has to be neighborhood-based, not metropolitan-areabased, since our estimates include fixed effects for each lender, and the applicants would have to be more creditworthy in terms of characteristics that are not included in our first-stage estimates.

\section{Denial Rates in Low-income and Minority Neighborhoods}

In this and the following subsections, we examine the extent to which the internal and external effects identified in the previous section can account for the observed differences in denial rates across neighborhoods arrayed by median family income and by percent minority population. We begin by documenting neighborhood differences in actual denial rates and denial rates adjusted for applicant characteristics. We then use our estimates of the internal and external effects from the previous section to estimate 
the extent to which cross-tract differences in adjusted denial rates are attributable to differences in internal and external effects for individual lenders.

Loan denial rates arrayed by median family income in the tract are presented in figure 1. Denial rates arrayed by minority percentage in the tract are presented in figure 2. Each figure shows two separate denial rates: 1) the actual denial rate controlling for nothing (equivalent to the numbers presented in table 3), and 2) the denial rate adjusted for individual characteristics using the coefficient estimates from the first-stage analysis (table 3 ). The adjusted denial rates are normalized to equal the actual denial rate in tracts with median incomes of $\$ 80,000$ or more (figure 1) and in tracts with a minority population of less than 1 percent (figure 2).

The gap in actual denial rates between low- and high-income tracts is huge: 31.3 percent of all loan applications for properties in tracts with median family incomes of less than $\$ 10,000$ are rejected, compared with 12.9 percent in tracts with median incomes of $\$ 80,000$ or more. Moreover, although much of the difference disappears when individual characteristics are controlled for, a significant difference remains: The gap between the denial rates in the lowest and highest income tracts is reduced from 18.4 to 10.3 percentage points.

The gap in actual denial rates between white and minority neighborhoods (defined by the percent minority population in the tract) is also quite large, and can also be attributed in large part to differences in the characteristics of individual applicants. The difference between the all-white and all-minority tracts, for example, falls from 
16.7 percentage points when nothing is controlled for, to 8.0 percentage points when individual characteristics are controlled for.

\section{Information Effects on Neighborhood Denial Rates}

For each tract, the internal and external information effects equal the weighted sums of the information effects for each lender in the tract, where the weights reflect each lender's share of total applications in the tract. Thus, the extent to which the internal and external effects of information, identified for individual lenders in tables 4 and 5, contribute to the observed differences in denial rates across tracts will depend on the size distribution of lenders within and across tracts, as well as the relative number of total applications in each tract. Figure 3 arrays various tract characteristics, including the average number of applications per lender and total applications, by median family income of the tract and by percent minority. On average, individual lenders receive relatively few applications from low-income and minority tracts, therefore, the inability to exploit internal economies of scale lending in these neighborhoods may account for a portion of the higher observed denial rates. The total number of applications in these tracts is also lower than in the higher-income and majority tracts. Given our estimate of a slightly positive external effect of information for individual lenders, this may actually work in favor of applicants for properties in low-income and minority tracts.

To calculate the internal information effect for each tract, we first calculate the internal information effect for each lender-tract combination based on the actual number of applications in the lender-tract and the coefficients from our basic 
regression, reported in table 4. For each lender this is the difference between the predicted denial rate for that lender and for a hypothetical lender, otherwise identical, that processes fewer than three applications in the tract (the omitted category in table 4). The internal information effect for each lender in the tract is then weighted by the lender's share of total applications for the tract to construct the effect for the tract.

In figure 4, the external and internal information effects are arrayed by the median family income (measured in thousands of dollars) in the tract. The information effects are the weighted averages of the individual tract effects where the weights are each tract's share of total applications from tracts in that income category. These effects are then normalized to have a value of zero in tracts with median family incomes below $\$ 10,000$. The internal information effect plotted in figure 4 shows our estimates of the difference in denial rates across tracts with different median family incomes that is attributable to the size distribution of lenders in the tracts relative to the size distribution of lenders in the lowest income tracts. Similarly, the external information effect is our estimate of the differences in denial rates that is attributable to differences in the total number of applications processed. The total effect is the sum of the external and internal information effects.

The internal information effect declines steadily as median tract income increases, up to a median family income of $\$ 30,000$, and is relatively constant beyond $\$ 30,000$. The estimates indicate that, independent of other factors, we would expect denial rates to decrease as median family income increases because individual lenders 
tend to process more applications from the same tract. According to these estimates, 1 percentage point of the difference in adjusted denial rates between tracts with a median family income below $\$ 10,000$ and those with a median family income of $\$ 30,000$ is attributable to differences in the economies of scale in private information realized by lenders in these tracts. This is almost one-third of the 3.5 percentage point difference in the adjusted denial rates in these tracts (figure 1). The external information effect increases as median family income increases up to about $\$ 45,000$ and then levels off.

In figure 5, the external and internal information effects are arrayed by the percentage minority population in the tract. The effects are normalized to have a value of zero in all minority tracts. While somewhat less striking than the estimates by median family income, the internal information effect declines steadily as the percent minority in the tract decreases, and accounts for .64 percentage point of the 8.0 percentage point difference in adjusted denial rates in all minority and all white tracts. Again, the external information effect increases as the percent minority population increases, though, since this effect tends to be smaller, the total effect is negative. 


\section{CONCLUSIONS}

The Community Reinvestment Act of 1977 was a response to concerns that certain neighborhoods, primarily low-income and minority neighborhoods, were being underserved by lenders. The primary method of enforcing the CRA has been to require all lenders to be active in community lending, punishing those who do not comply. Our finding that economies of scale in neighborhood lending accrue to the individual lenders suggests that forcing all lenders to be active in all neighborhoods may inhibit lending to the most underserved neighborhoods, where there are relatively few transactions.

Based strictly on information dynamics, efficiency would be increased if individual lenders were allowed to specialize so that they could achieve the critical mass of applications required to exploit the economies of scale in neighborhood lending. However, when designing the compliance mechanism for CRA, regulators need to weigh potential efficiency gains from having a few specialized lenders in an area against the potential losses that may result if these lenders can exploit monopoly power and limit the number of loans to the neighborhood. Alternative enforcement mechanisms that might be more efficient than the current system include allowing individual lenders to meet their CRA obligations by helping to finance banks specializing in community lending; a regulated monopoly; or a system of tradeable permits like the one suggested by Klausner (1995). 


\section{REFERENCES}

Avery, Robert B., Patricia E. Beeson, and Mark S. Sniderman, 1994. Underserved Mortgage Markets: Evidence From HMDA Data. Working Paper 9421, Federal Reserve Bank of Cleveland.

Avery, Robert B. and Thomas M. Buynak, 1981. Mortgage Redlining: Some New Evidence. Economic Review, Federal Reserve Bank of Cleveland (Summer).

Barth, James R., Joseph J. Cordes, and Anthony M.J. Yezer, 1979. Financial Institution Regulations, Redlining, and Mortgage Markets. In The Regulation of Financial Institutions, Conference Series 21, Federal Reserve Bank of Boston, pp. 101-43.

Benston, G.J., 1979. Mortgage Redlining Research: a Review and Critical Analysis. In The Regulation of Financial Institutions, Conference Series 21, Federal Reserve Bank of Boston, pp. 101-43.

Bradbury, Katherine L., Karl E. Case, and Constance R. Dunham, 1989. Geographic Patterns of Mortgage Lending in Boston, 1982-1987. New England Economic Review (September/October), pp. 3-30.

Calem, Paul S., forthcoming. Mortgage Credit Availability in Low- and ModerateIncome Minority Neighborhoods: Are Information Externalities Critical? Journal of Real Estate Finance and Economics.

Canner, Glenn B., 1981. Redlining and Mortgage Lending Patterns. In Research in Urban Economics, edited by J. Vernon Henderson, Greenwich, CT: JAI Press, pp. 67101.

Canner, Glenn B., Stuart A. Gabriel, and J. Michael Wooley. 1991. Race, Default Risk, and Mortgage Lending: A Study of the FHA and Conventional Loan Markets.

Southern Economic Journal, Vol. 58 (No. 2), pp. 249-262.

Canner, Glenn B. and Delores S. Smith, 1991. Home Mortgage Disclosure Act:

Expanded Data on Residential Lending. Federal Reserve Bulletin, vol. 77 (November), pp. 859-881.

Duca, John V., and Stuart S. Rosenthal, 1993. Borrowing Constraints, Household Debt, and Racial Discrimination in Loan Markets. Journal of Financial Intermediation, No. 3. 
Gabriel, Stuart A., and Stuart Rosenthal, 1991. Credit Rationing, Race, and the Mortgage Market. Journal of Urban Economics, vol. 73, no. 3 (May), pp. 393-410.

Gruben, William C., Jonathan A. Neuberger, and Ronald H. Schmidt, 1990. Imperfect Information and the Community Reinvestment Act. Economic Review, Federal Reserve Bank of San Francisco (Summer), pp. 27-46.

Guttentag, Jack M., and Susan L. Wachter, 1980. Redlining and Public Policy. Monograph Series on Finance and Economics, No. 1, Solomon Brothers Center for the Study of Financial Institutions, New York.

Klausner, Michael, 1995. Market Failure and Community Investment: A MarketOriented Alternative to the Community Reinvestment Act. University of Pennsylvania Law Review, vol. 143, no. 5 (May), pp. 1561-93.

Lang, William W., and Leonard I. Nakamura, 1993. A Model of Redlining. Journal of Urban Economics, vol. 33, no. 2 (March), pp. 223-34.

Stiglitz, Joseph E., and Andrew Weiss, 1981. Credit Rationing in Markets with Imperfect Information. American Economic Review, vol. 71 (June), pp. 393-410.

Stiglitz, Joseph E., and Andrew Weiss, 1987. Credit Rationing with Many Borrowers. American Economic Review, vol. 77 (March), pp. 228-231. 


\section{Figure 1 Actual and Adjusted Denial Rates}

by Median Family Income in Tract

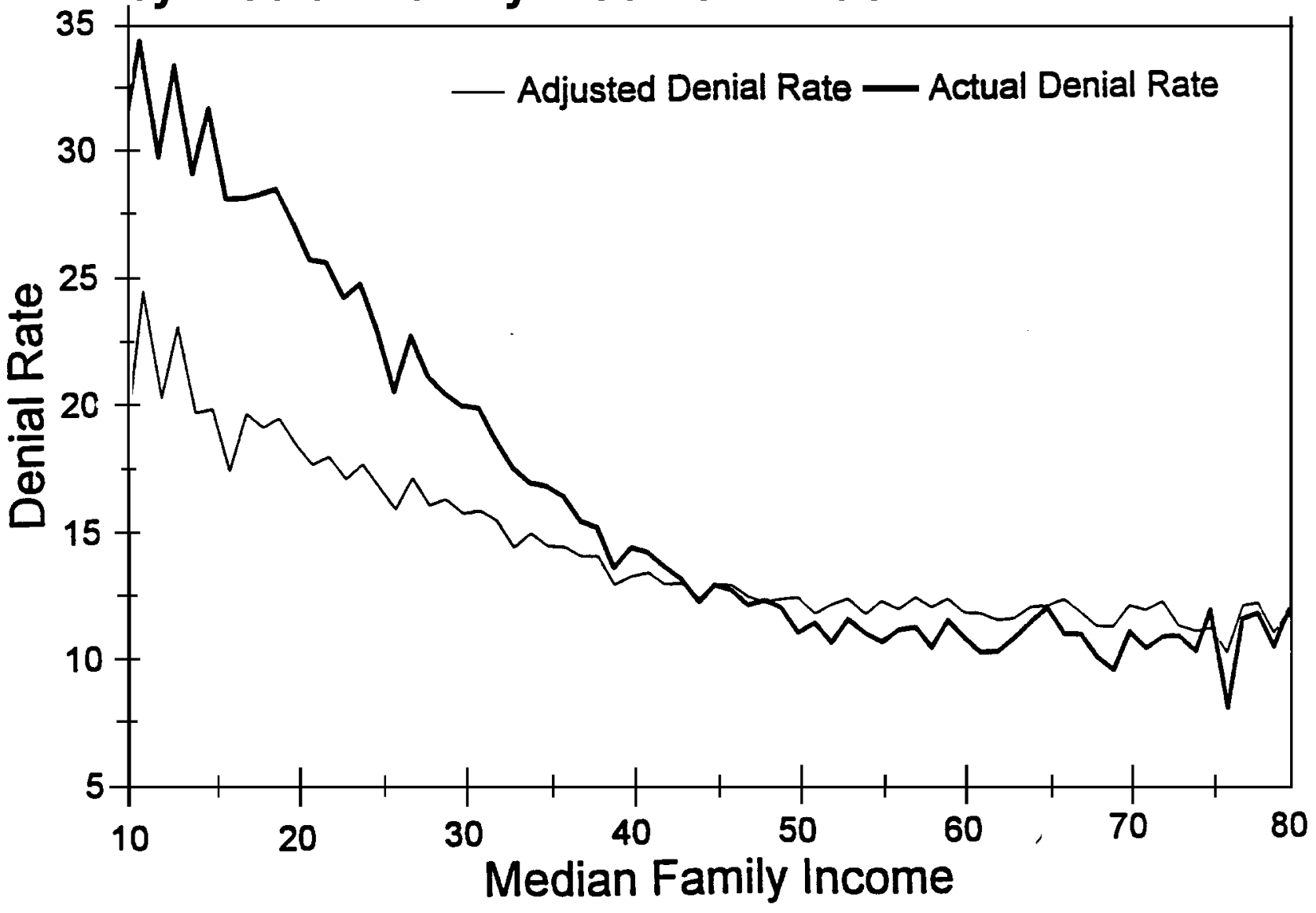

Source: Authors' Calculations. 
Figure 2

\section{Actual and Adjusted Denial Rates by Percent Minority in Tract}

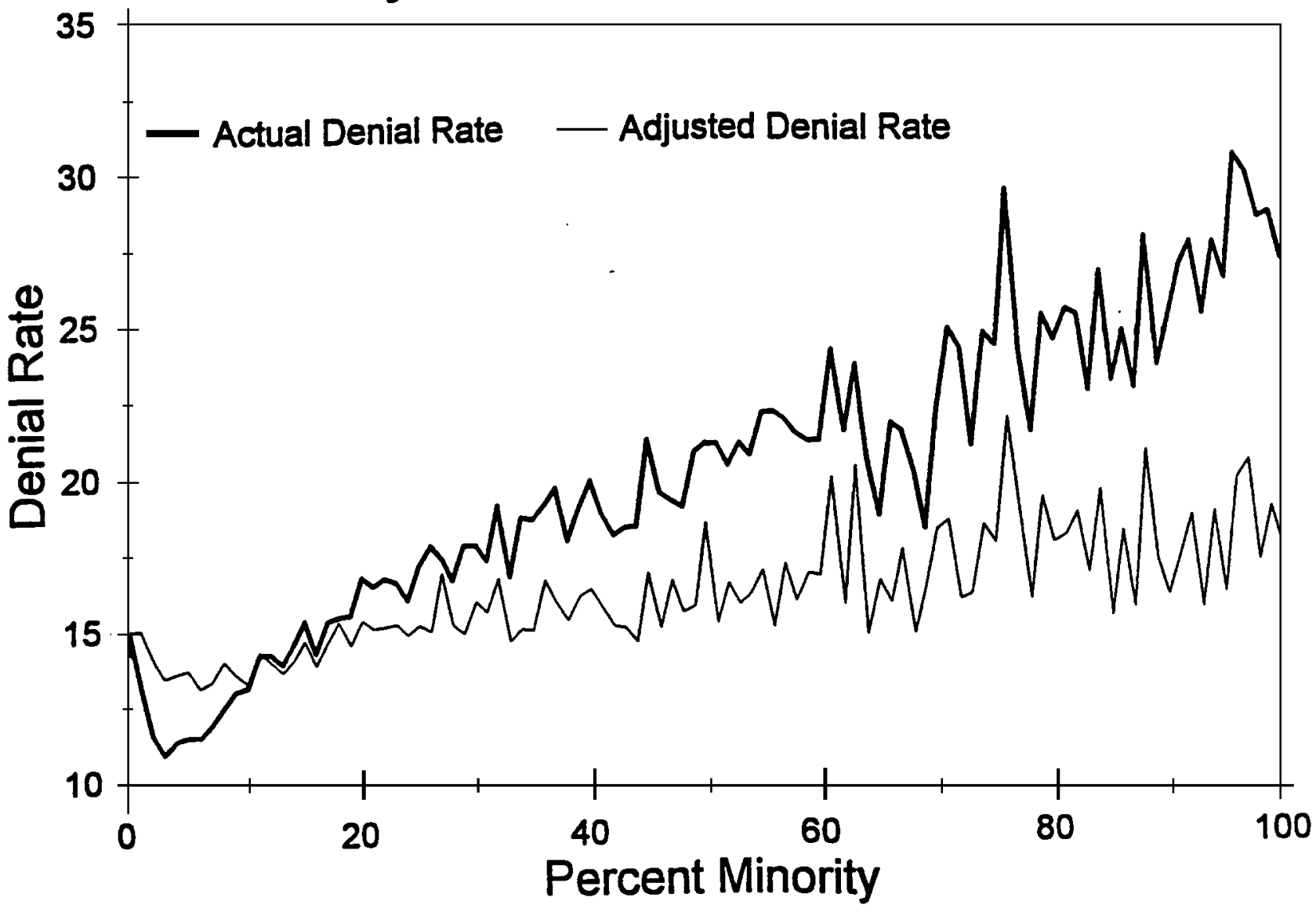

Source: Authors' Calculations. 


\section{Figure 3}

Average Number of Lenders per Tracx by Median Family Income

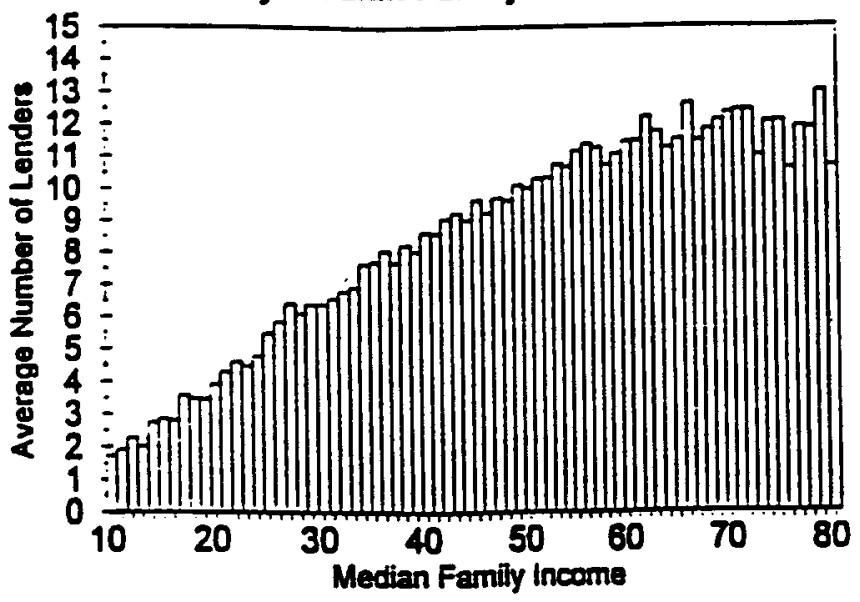

Applications per Lender per Tract by Median Family Income

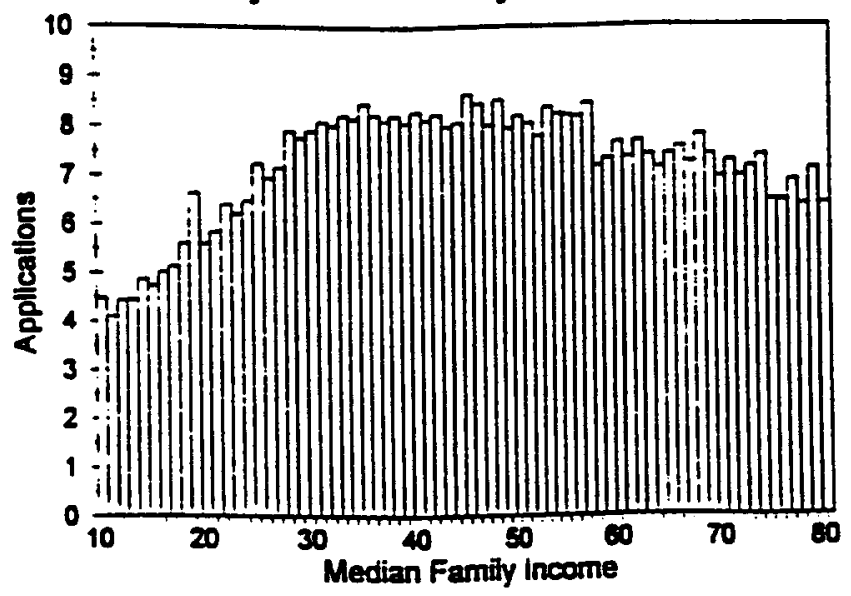

Applications per Tract

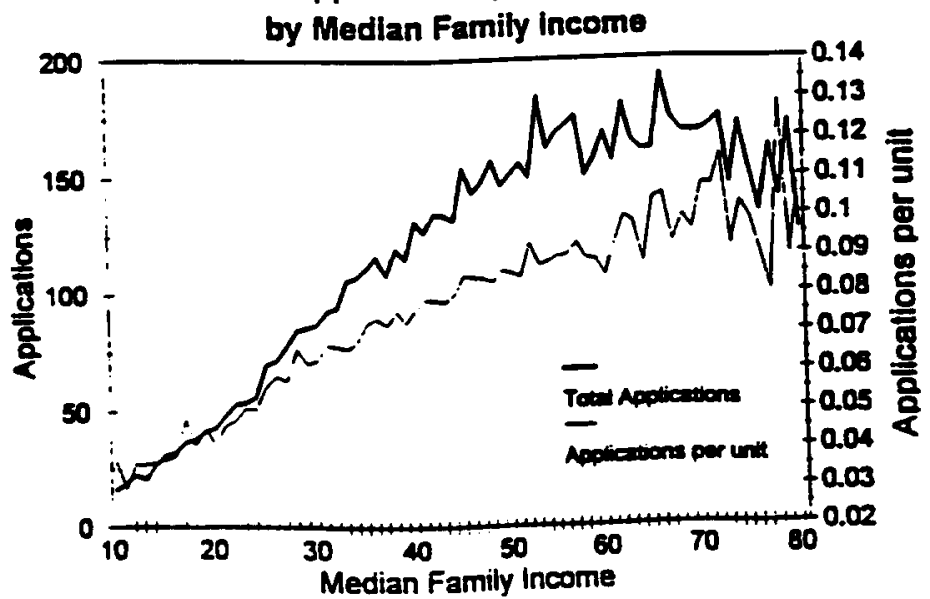

Average Number of Lenders per Tract by Percent Minority

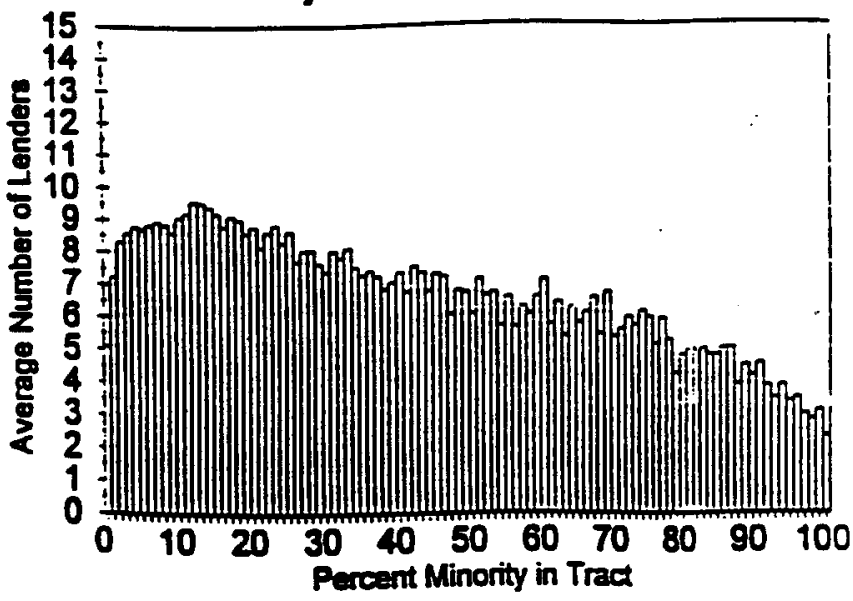

Applications per Lender per Tract by Percent Minority

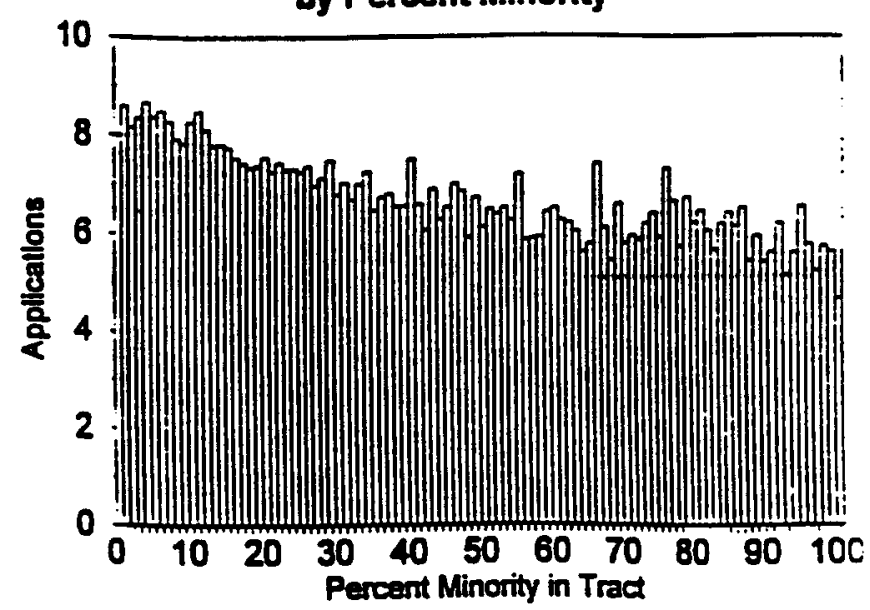

Applications per Tract

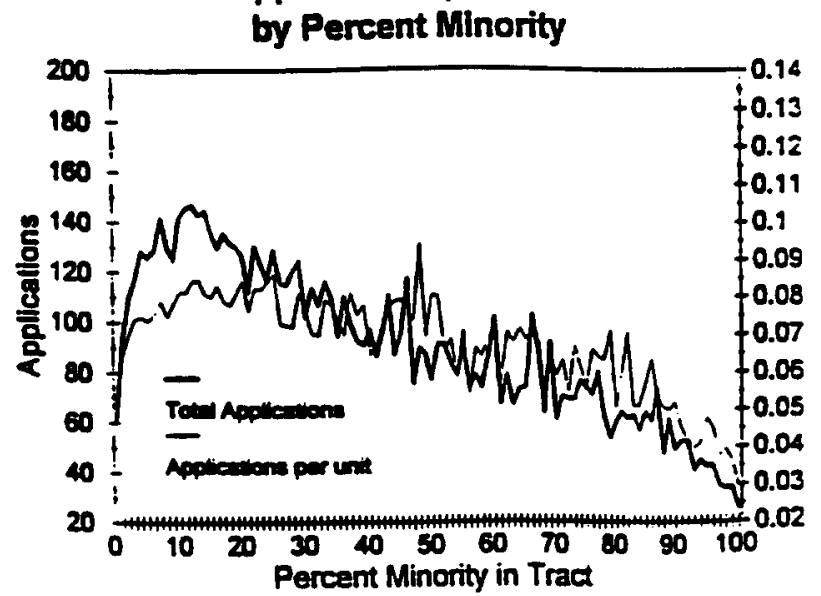

Source: Authors' Calculations. 
Figure 4

\section{Internal and External Effects on Denial Rates, by Median Family Income}

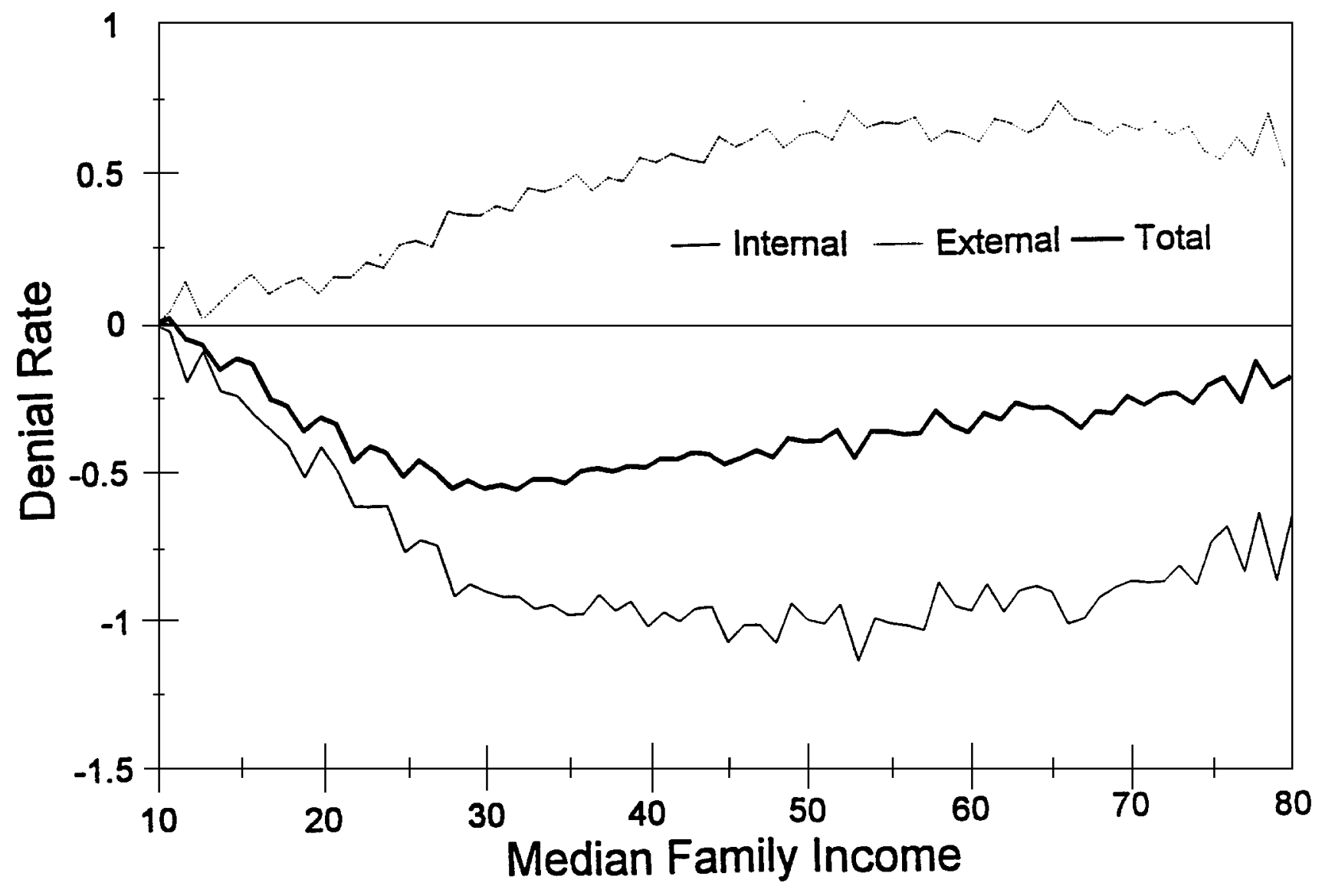

Source: Authors' Calculations. 


\section{Figure 5}

\section{Internal and External Effects on Denial Rates, by Percent Minority}

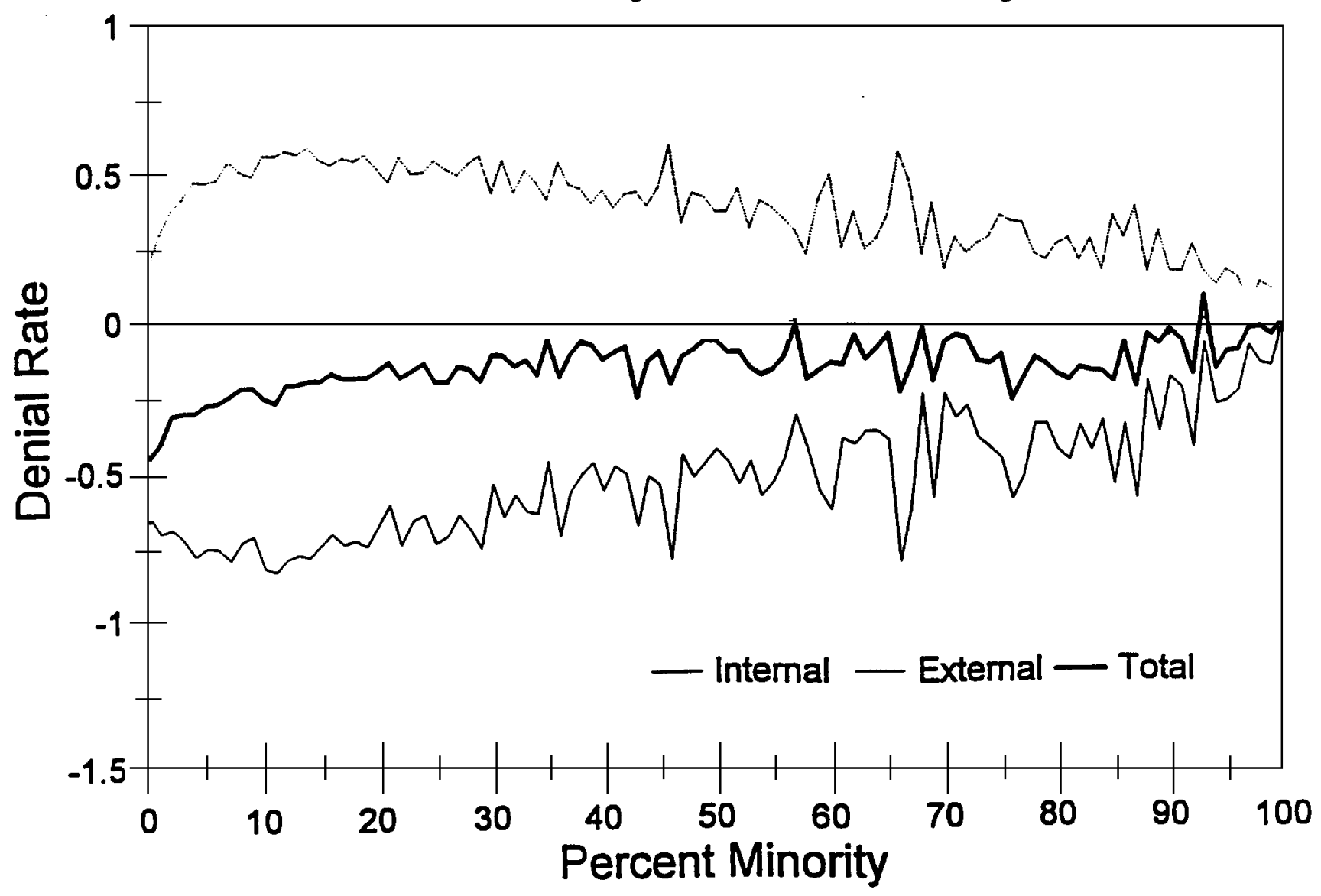

Source: Authors' Calculations. 
Table 1: Characteristics of Mortgage Applications, National Sample, 1990 and 1991 HMDA

\begin{tabular}{|c|c|c|c|c|}
\hline & \multicolumn{3}{|c|}{ Home Purchase Loan Applications } & \\
\hline & $\begin{array}{l}\text { Percent of } \\
\text { Sample }\end{array}$ & $\begin{array}{l}\text { Percent of } \\
\text { Loan dollars }\end{array}$ & $\begin{array}{l}\text { Denial } \\
\text { Rate }\end{array}$ & \\
\hline \multicolumn{5}{|l|}{ Race of Applicant } \\
\hline Native American & $.5 \%$ & $.5 \%$ & $20.2 \%$ & \\
\hline Asian (or Pacific Islander) & 4.4 & 6.4 & 15.5 & \\
\hline Black & 6.1 & 4.7 & 29.2 & \\
\hline Hispanic & 6.4 & 6.2 & 23.2 & \\
\hline White & 81.9 & 81.2 & 13.6 & 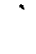 \\
\hline Other & .7 & 1.0 & 20.2 & \\
\hline Race of Co-applicant & & & $\cdot$ & \\
\hline No Co-applicant & 28.7 & 24.3 & 18.1 & \\
\hline Same Race as Applicant & 69.3 & 73.4 & 14.2 & \\
\hline Different Race than Applicant & 2.0 & 2.3 & 15.5 & \\
\hline \multicolumn{4}{|l|}{ Income of Applicant } & \\
\hline Less than $\$ 25,000$ & 13.2 & 5.4 & 29.0 & \\
\hline$\$ 25,000$ to $\$ 50,000$ & 39.9 & 28.0 & 15.0 & \\
\hline$\$ 50,000$ to $\$ 75,000$ & 24.5 & 26.0 & 11.5 & \\
\hline$\$ 75,000$ to $\$ 100,000$ & 10.1 & 14.1 & 11.5 & \\
\hline More than $\$ 100,000$ & 12.3 & 26.6 & 12.4 & \\
\hline \multicolumn{4}{|l|}{ Loan Request } & \\
\hline Less than $\$ 50,000^{1}$ & 25.0 & 7.8 & 23.9 & \\
\hline$\$ 50,000$ to $\$ 75,000^{1}$ & 21.8 & 13.7 & 12.9 & \\
\hline$\$ 75,000$ to $\$ 125,000^{1}$ & 29.9 & 29.6 & 11.0 & \\
\hline More than $\$ 125,000^{1}$ & 23.3 & 48.9 & 13.9 & \\
\hline \multicolumn{4}{|l|}{ Gender } & \\
\hline Male Applicant, Female Co-applicant & 64.0 & 68.3 & 13.7 & \\
\hline Female Applicant, Male Co-applicant & 4.3 & 4.1 & 18.9 & \\
\hline Male Applicant and Co-applicant & 1.9 & 2.1 & 17.7 & \\
\hline Female Applicant and Co-applicant & 1.3 & 1.2 & 19.8 & \\
\hline Single Male Applicant & 16.9 & 15.6 & 18.9 & \\
\hline Single Female Applicant & 11.8 & 8.7 & 16.9 & \\
\hline Owner-Occupied & 93.6 & 94.6 & 15.3 & \\
\hline \multicolumn{5}{|l|}{ Loan Type } \\
\hline Conventional & 74.7 & 82.3 & 15.5 & \\
\hline FHA & 20.1 & 13.8 & 14.4 & \\
\hline VA 5.1 & 3.9 & 16.2 & & \\
\hline FmHA & .02 & .02 & 28.4 & \\
\hline
\end{tabular}


Table 1: (Continued)

Home Purchase Loan Applications

Percent of

Percent of

Sample

Loan dollars

Lender Action

Loan Denied

15.3

14.0

Loan Accepted and Withdrawn

2.7

3.2

Loan Originated

82.0

82.7

Loan Kept by Originator ( $\%$ of originations)

42.9

45.1

Loan Sold to FNMA (\% of originations)

15.2

15.2

Loan Sold to GNMA (\% of originations)

11.0

8.0

Loan Sold to FHLMC (\% of originations)

9.4

9.4

Loan Sold Elsewhere ( $\%$ of originations)

21.5

22.4

Reasons for Denial (of Loans Denied) ${ }^{2}$

No Reason Given

31.3

28.7

Debt-to-Income Ratio

17.1

19.3

Employment History

4.2

3.1

Credit History

26.3

21.9

Collateral

8.3

9.4

Insufficient Cash

4.1

4.5

Unverifiable Information

2.9

4.2

Application Incomplete

3.0

4.3

Mortgage Insurance Denied

.9

1.0

Other

14.5

17.5

Memo Items:

Median Income (\$1,000s)

Median Loan Request $(\$ 1,000$ s)

Number of Loans

\section{$\$ 48$}

$\$ 78$

$4,072,158$

${ }^{1}$ Up to three reasons for denial could be given, and answers were voluntary. Each category gives the percent of all denials that gave that reason as one of the three.

Source: Authors' calculation. 
Table 2: Distribution of 1990 Census Population and 1990/1991 HMDA Loan Applications by Tract Characteristics ${ }^{1}$

\section{Portion of all \\ 1-4 Family Units}

Portion of

Applications

Home Purchase Loans

Total Minority

Denial Rates

White Black Hispanic

Level \& Change in Minority Population Share

Less than 5 Percent Minority, 1990

5 to 10 Percent Minority, 1990

Rose < 5 Percent from 1980

Rose $>5$ Percent from 1980

10 to 50 Percent Minority, 1990

Rose < 5 Percent from 1980

Rose 5 to 15 Percent from 1980

Rose $>15$ Percent from 1980

50 Percent or more Minority, 1990

Rose < 5 Percent from 1980

Rose 5 to 15 Percent from 1980

Rose > 15 Percent from 1980

$\begin{array}{rrllll}27.9 \% & 27.8 \% & 5.1 \% & 11.9 \% & 26.5 \% & 19.4 \% \\ 18.2 & 20.0 & 8.4 & 11.8 & 25.1 & 19.9 \\ 17.0 & 18.9 & 7.7 & 11.8 & 25.0 & 20.1 \\ 1.2 & 1.2 & .8 & 12.6 & 26.3 & 18.3 \\ 37.5 & 41.4 & 47.1 & 15.0 & 28.0 & 21.8 \\ 14.2 & 16.5 & 12.2 & 14.5 & 30.7 & 22.5 \\ 18.6 & 20.3 & 24.1 & 14.9 & 26.9 & 21.7 \\ 4.7 & 4.6 & 10.7 & 17.8 & 27.0 & 21.2 \\ 16.3 & 10.8 & 39.4 & 21.4 & 31.0 & 26.0 \\ 6.9 & 3.3 & 12.2 & 21.3 & 32.5 & 29.7 \\ 4.3 & 2.9 & 10.1 & 21.8 & 32.3 & 26.9 \\ 5.2 & 4.6 & 17.2 & 21.2 & 28.7 & 23.5\end{array}$

Median Family Income, 1990

Less than $\$ 20,000$

$\$ 20,000$ to $\$ 30,000$

$\$ 30,000$ to $\$ 40,000$

$\$ 40,000$ or More

Center City, MSA size, 1990

Center City

MSA Less than 1 million

MSA 1 to 2 million

MSA More than 2 million

Non-Center City

MSA Less than 1 million

MSA 1 to 2 million

MSA More than 2 million

$\begin{array}{rrrrrr}6.6 & 2.6 & 7.1 & 24.6 & 37.9 & 32.5 \\ 18.7 & 13.3 & 19.4 & 20.8 & 34.8 & 26.7 \\ 29.8 & 29.1 & 28.1 & 15.1 & 28.4 & 22.8 \\ 44.8 & 55.0 & 45.3 & 10.9 & 23.7 & 19.6\end{array}$

$\begin{array}{rrrrrr}22.5 & 20.6 & 18.3 & 14.1 & 33.7 & 27.0 \\ 6.7 & 6.2 & 8.0 & 13.8 & 30.5 & 26.8 \\ 15.0 & 13.1 & 24.4 & 15.2 & 28.7 & 22.8\end{array}$

22.

9.1

24.0
22.4

10.0

27.7
10.9

6.6

31.7
$14.4 \quad 31.4$

$12.1 \quad 28.8$

$12.3 \quad 23.5$

' Percentages sum to 100 for each group for each column.

Source: Authors' calculation. 
Table 3: Linear Probability Model of Loan Denial (1) or Acceptance (0), Home Purchase Loan Applications

\begin{tabular}{|c|c|c|c|c|}
\hline \multirow[b]{2}{*}{ Owner-occupied (Dummy) } & \multicolumn{2}{|c|}{$\begin{array}{c}1990 \\
\text { Coefficient Standard Error }\end{array}$} & \multicolumn{2}{|c|}{$\begin{array}{c}1991 \\
\text { Coefficient Standard Error }\end{array}$} \\
\hline & $.00649^{* * *}$ & .00132 & $.00979^{* * *}$ & .00136 \\
\hline \multicolumn{5}{|l|}{ Race (Dummies, "White" Is Base Group) } \\
\hline Native American Applicant & $.02636^{* \cdots *}$ & .00703 & $.04332^{* * * *}$ & .00685 \\
\hline Asian Applicant & .00171 & .00472 & $.01180^{*}$ & .00467 \\
\hline Black Applicant & $.10385^{* * \bullet}$ & .00478 & $.10552^{* * * *}$ & .00474 \\
\hline Hispanic Applicant & $.03841^{* \cdots *}$ & .00463 & $.05226^{* * *}$ & .00461 \\
\hline Other Race Applicani & $.03043^{* * *}$ & .00432 & $.05425^{* * *}$ & .00426 \\
\hline Mixed Race, Minority Co-applicant (Dummy) & $.00764^{* *}$ & $.0026 \dot{8}$ & .00047 & .00258 \\
\hline Mixed Race, Non-minority Co-applicant (Dummy) & $-.02324^{* * *}$ & .00294 & $-.03102^{* * *}$ & .00286 \\
\hline \multicolumn{5}{|l|}{ Income, Interacted With Race } \\
\hline Native American Applicant & $-.00983^{* * *}$ & .00034 & $-.01060^{* * *}$ & .00037 \\
\hline Asian Applicant & $-.00974^{* * *}$ & .00034 & $-.01061^{* * *}$ & .00037 \\
\hline Black Applicant & $-.00986^{* * *}$ & .00034 & $-.01074^{* * *}$ & .00037 \\
\hline Hispanic Applicant & $-.00981^{* \cdots *}$ & .00034 & $-.01068^{* * *}$ & .00037 \\
\hline White Applicant & $-.00983^{* * *}$ & .00034 & $-.01065^{* * *}$ & .00037 \\
\hline Other Race Applicant & $-.00982^{* * *}$ & .00034 & $-.01073^{* * *}$ & .00037 \\
\hline \multicolumn{5}{|l|}{ Income Splines (\$1,000's) } \\
\hline Income Spline at $\$ 20,000$ & $.00604^{* \cdots *}$ & .00038 & $.00644^{* * *}$ & .00042 \\
\hline Income Spline at $\$ 40,000$ & $.00283^{* * *}$ & .00015 & $.00305^{\circ * *}$ & .00015 \\
\hline Income Spline at $\$ 60,000$ & $.00063^{* * *}$ & .00015 & $.00033^{*}$ & .00015 \\
\hline Income Spline at $\$ 80,000$ & .00013 & .00017 & $.00062^{* * *}$ & .00017 \\
\hline Income Spline at $\$ 100,000$ & .00012 & .00014 & .00002 & .00014 \\
\hline Income Spline at $\$ 150,000$ & -.00003 & .00010 & .00006 & .00010 \\
\hline Income Spline at $\$ 200,000$ & .00011 & .00006 & $.00012^{*}$ & .00006 \\
\hline \multicolumn{5}{|l|}{ Loan Amount (\$1,000's) } \\
\hline Loan Amount & $-.00191^{\circ * * *}$ & .00020 & $-.0 \dot{0} 213^{* * *}$ & .00020 \\
\hline Loan Amount Spline at $\$ 20,000$ & .00027 & .00027 & $.00104^{* * *}$ & .00027 \\
\hline Loan Amount Spline at $\$ 40,000$ & $.00179^{* * *}$ & .00018 & $.00107^{* * *}$ & .00018 \\
\hline Loan Amount Spline at $\$ 60,000$ & -.00019 & .00016 & $.00037^{*}$ & .00016 \\
\hline Loan Amount Spline at $\$ 80,000$ & $.00038^{*}$ & .00016 & .00015 & .00016 \\
\hline Loan Amount Spline at $\$ 100,000$ & -.00020 & .00011 & $-.00024^{*}$ & .00010 \\
\hline Loan Amount Spline at $\$ 150,000$ & $.00022^{* * *}$ & .00006 & $.00047^{40 *}$ & .00006 \\
\hline Loan Amount Spline at $\$ 200,000$ & $-.00029^{* * *}$ & .00004 & $-.00059^{* * *}$ & .00004 \\
\hline \multicolumn{5}{|c|}{ Loan-to-Income Ratio (Dummies, Less than 1.5 Is Base Group) } \\
\hline Ratio of 1.5 to 2.0 & -.01012 & .00105 & $-.01661^{* * *}$ & .00106 \\
\hline Ratio of 2.0 to 2.25 & $-.01158^{* * *}$ & .00141 & $-.02318^{* * *}$ & .00142 \\
\hline Ratio of 2.25 to 2.5 & $-.01176^{* * *}$ & .00163 & $-.02301^{* * *}$ & .00163 \\
\hline Ratio of 2.5 to 2.75 & $-.00713^{* * *}$ & .00187 & $-.02103^{* * * *}$ & .00185 \\
\hline Ratio of 2.75 to 3.0 & .00362 & .00227 & $-.00979^{* * *}$ & .00224 \\
\hline Ratio over 3.0 & $.05105^{* * *}$ & .00207 & $.05014^{* * *}$ & .00210 \\
\hline
\end{tabular}


Table 3: (Continued)

1990

1991

Coefficient Standard Error Coefficient Standard Error

Applicant Gender (Dummies, Female Applicant, No Co-applicant Is Base Group)

Male Applicant, Female Co-applicant

$-.01875^{\circ} \quad .00763$

Female Applicant, Male Co-applicant

$-.00726$

.00772

$-.00354 \quad .00787$

Male Applicant and Co-applicant

$-.00984$

.00800

Male Applicant, No Co-applicant

$.02815^{* * *} \quad .00109$

$\begin{array}{ll}-.02737^{* * *} & .00811 \\ -.00902 & .00819 \\ -.00281 & .00838 \\ .00750 & .00845 \\ .02549^{* * *} & .00106\end{array}$

Income, Interacted With No Co-applicant

Income

Income Spline at $\$ 20,000$

Income Spline at $\$ 40,000$

Income Spline at $\$ 60,000$

Income Spline at $\$ 80,000$

Income Spline at $\$ 100,000$

$\begin{array}{cccc}-.00332^{* * *} & .00042 & -.00409^{* * *} & .00045 \\ .00514^{* * *} & .00049 & .00581^{* * *} & .00052 \\ -.00051^{*} & .00024 & -.00059^{* *} & .00024 \\ -.00137^{* * *} & .00030 & -.00052 & .00031 \\ .00049 & .00036 & .00028 & .00037 \\ -.00045^{*} & .00020 & -.00093^{* * *} & .00020\end{array}$

Race and Marital Status, Interacted With VA Loan

Native American Applicant

Asian Applicant

Black Applicant

Hispanic Applicant

White Applicant

Other Race Applicant

No Co-Applicant

$\begin{array}{rr}.05046^{*} & .02211 \\ .02433 & .01766 \\ -.00559 & .01470 \\ -.00742 & .01548 \\ -.01859 & .01428 \\ .03077 & .02727 \\ -.00617^{*} & .00311\end{array}$

$-.05608^{* *}$

.02089

$-.00575$

.01671

$-.01431$

.01470

$-.02767$

.01527

$-.03088$

.01436

$.01728^{*}$

.02360

$-.01267^{* *}$

.00276

Race and Marital Status, Interacted With FHA Loan

Native American Applicant

Asian Applicant

$.00605 \quad .01708$

.01490

$-.01909$

.01743

$-.02650$

.01446

Black Applicant

$-.01816$

$-.04396$

.01502

Hispanic Applicant

White Applicant

$-.04093^{* *} \quad .01446$

$-.03974^{* *}$

.01457

$.03139^{*} \quad .01424$

$-.05980^{* *}$

.01454

Other Race Applicant

No Co-Applicant

$-.01913 \quad .01735$

$-.04720^{* *}$

.01435

$-.05510^{* * *} \quad .01715$

$.01235^{\circ * *} \quad .00164$

$-.01477^{* * *}$

.00162

Income, Interacted With VA or FHA Loan

Income

Income Spline at $\$ 20,000$

Income Spline at $\$ 40,000$

Income Spline at $\$ 60,000$

Income Spline at $\$ 80,000$

Income Spline at $\$ 100,000$

$\begin{array}{ll}-.00171^{* *} & .00054 \\ .00297^{* * *} & .00058 \\ -.00033 & .00024 \\ -.00130^{* \ldots *} & .00034 \\ .00197^{* \ldots *} & .00052 \\ -.00158^{* \cdots *} & .00034\end{array}$

$-.00117^{*} \quad .00056$

$.00243^{* 0 *} \quad .00060$

$-.00059^{*} \quad .00024$

$-.00018 \quad .00032$
.00070

$.00070 \quad .00048$

$-.00125^{* * *} \quad .00031$ 
Loan Amount, Interacted With VA or FHA Loan

Loan Amount

Loan Amount Spline at $\$ 20,000$

Loan Amount Spline at $\$ 40,000$

Loan Amount Spline at $\$ 60,000$

Loan Amount Spline at $\$ 80,000$

Loan Amount Spline at $\$ 100,000$

$\begin{array}{cccc}.00359^{* * *} & .00053 & .00399^{* * *} & .00050 \\ -.00249^{* * *} & .00069 & -.00324^{* * *} & .00068 \\ -.00230^{* * *} & .00034 & -.00156^{* * *} & .00035 \\ .00067^{*} & .00027 & -.00015 & .00027 \\ -.00043 & .00027 & -.00000 & .00026 \\ .00058^{*} & .00026 & .00078^{* *} & .00024\end{array}$

Loan-to-Income Ratio, Interacted With VA or FHA Loan

Ratio of 1.5 to 2.0

Ratio of 2.0 to 2.25

$\begin{array}{ll}-.00335 & .00222 \\ -.00521 & .00299\end{array}$

.00305

.00223

.00351

.00299

.00089

.00345

$-.00625$

.00347

.00011

.00397

.00355

00392

Ratio of 2.5 to 2.75

$-.00476 \quad .00475$

$-.00044$

00464

Ratio Over 3.0

$-.00935$

.00484

Month of Decision (Dummies, December Is Base Group)

\section{January \\ February \\ March \\ April \\ May \\ June}

July

August

September

October

November

$\begin{array}{ll}.01867^{* * *} & .00159 \\ .02085^{* * *} & .00155 \\ .01328^{* * *} & .00143 \\ .01376^{* * *} & .00142 \\ .00954^{* * *} & .00139 \\ .00382^{* *} & .00138 \\ .01062^{* * *} & .00140 \\ .00796^{* * *} & .00137 \\ .01078^{* * *} & .00143 \\ .01498^{* * *} & .00142 \\ .00740^{* * *} & .00146\end{array}$

Memo Items:

Number of Observations

Mean Denial Rate in Regression Sample

Number of Tract/Institution Dummies

R Squared (Including Tract/Institution Dummies)

R Squared (Variation around Tract/Institution Means)
$1,984,688$

.148

607,631

.457

.022
$2,087,470$

.157

662,571

.478

.025

$\begin{array}{ll}.03988^{* * *} & .00154 \\ .03658^{* * *} & .00152 \\ .03091^{\cdots * *} & .00140 \\ .03169^{* * *} & .00135 \\ .01819^{* \cdots *} & .00131 \\ .00538^{* * *} & .00130 \\ .02486^{* * *} & .00133 \\ .01600^{* * *} & .00132 \\ .01816^{* * *} & .00137 \\ .01921^{* * *} & .00136 \\ .00893^{* * *} & .00140\end{array}$

- Significant at the 5 percent level.

** Significant at the 1 percent level.

*.* Significant at the .1 percent level.

Source: Authors' calculation. 
Table 4: Lender/tract Adjusted Loan Denial Rate Regression, Basic Models, Selected Coefficients

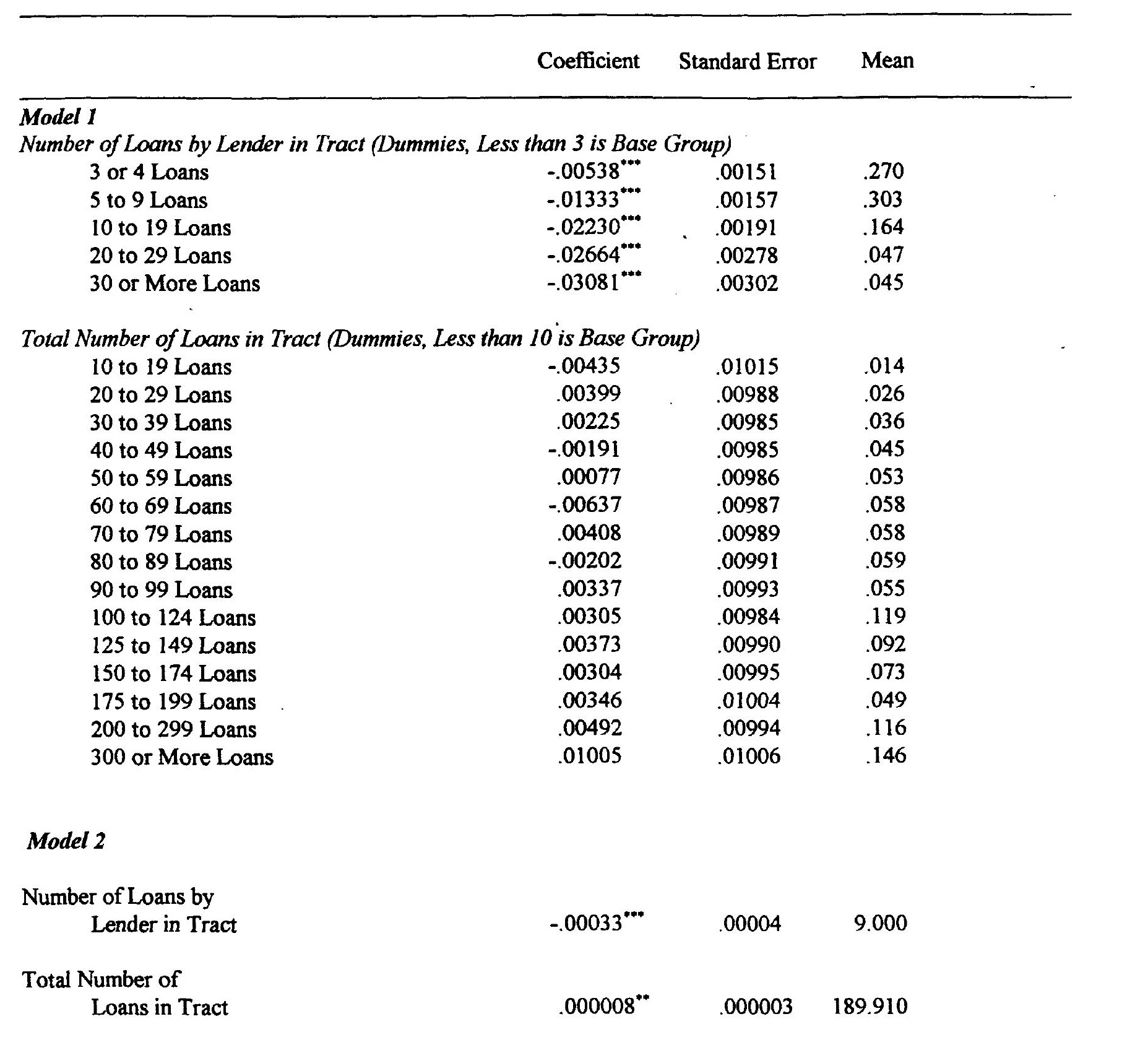

* $\quad * * *$ Significant at the 5,1 , and .1 percent levels, respectively.

Source: Authors' calculation. 
Table 5: Additional Lender/tract Adjusted Loan Denial Rate Regressions, Selected Coefficients

\section{Coefficient Standard Error Mean}

Model 3:

Lender Tract Market Share (Dummies, Less than 2 Percent is Base Group)

$\begin{array}{llll}2 \text { to } 5 \text { Percent } & -.00954^{* * *} & .00156 & .332 \\ 5 \text { to } 10 \text { Percent } & -.01629^{* * *} & .00179 & .259 \\ 10 \text { to } 15 \text { Percent } & -.02192^{* * *} & .00224 & .105 \\ 15 \text { to } 25 \text { Percent } & -.02468^{* * *} & .00253 & .077 \\ \text { More than 25 Percent } & -.03092^{* * *} & .00342 & .035\end{array}$

Ratio of Tract Applications to 1-4 Units (Dummies, Less than 3 Percent is Base Group)

3 to 5 Percent

5 to 7 Percent

7 to 9 Percent

9 to 11 Percent

11 to 13 Percent

13 to 15 Percent

15 to 17 Percent

17 to 19 Percent

19 to 21 Percent

21 to 23 Percent

23 to 25 Percent

25 to 27 Percent

27 to 29 Percent

29 to 31 Percent

31 or More Percent $-.00629^{\circ} \quad .00284$

$-.00751^{*} \quad .00299$

$-.00941^{* *} \quad .00316$

$-.00584 \quad .00336$

$-.00520 \quad .00361$

$-.00918^{\circ}$

.00390

.00435

.00480

.00563

.00640

.00713

.00860

.01045

.00944

.00581

$-.01373$

$-.01663^{*}$

$-.00082^{* \cdots}$

$-.00012$

.00008

Lender - Tract Market Share (\%)
Ratio of Tract Applications to 1-4 Units (\%)

8.960

Model 4:

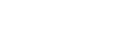

* Significant at the 5,1 , and .1 percent levels, respectively.

Source: Authors' calculation. 
Appendix Table 1: Lender/Tract Adjusted Denial Rate Regression, Basic Model, Coefficient Estimates

Coefficient Standard Error

Central City (Dummy=1)

$-.00894$

.00129

Minority Share of Tract Population 1990

Minority Share

.03115

.06676

Minority Share Spline at .05

.03745

.09680

Minority Share Spline at .10

$-.01656$

.05290

Minority Share Spline at .25

$-.05151$

.02448

Minority Share Spline at .50

.05570

.01811

Change in Minority Share 1980-90 (Dummies, less than zero is Base Group)

Rose 0-.05

$-.00012$

.00167

Rose .05-.10

.00088

.00210

Rose .10-.15

$-.00246$

.00258

Rose more than 15

$-.00043$

.00279

Median Family Income of the Tract, 1990

Median Family Income

$-.05264 \quad .04318$

Median Income Spline at $\$ 25,000$

$-.02130$

.04552

Median Income Spline at $\$ 40,000$

.00101

.02395

Median Income Spline at $\$ 55,000$

.05716

.01824

Change in Median Family Income 1980-90 (Dummies, less than 25 percent is Base Group)

Rose 25 to 50 percent

.01196

.01322

.00397

Rose 50 to 100 percent

.01319

.00412

Rose more than 100 percent

.00448

Median House Value, 1990

Median House Value

$-.08771$

.01860

Median House Value Spline at 50,000

.06136

.01353

.01971

Median House Value Spline at 100,000

.00560

.00840

Median House Value Spline at 150,000

.00536

Change in Median House Valuse 1980-90 (Dummies, less than \$25,000 is Base Group)

Rose $\$ 25,000-\$ 50,000$

.00550

.00225

Rose $\$ 50,000-\$ 100,000$

.00850

.00276

Rose $\$ 100,000-\$ 150,000$

.00900

.00345

Rose More than $\$ 150,000$

.00684

.00300

Median Age of Heads of Households

Share Age Group 2

Share Age Group 3

$-.01715$

.02639

Share Age Group 4

$-.00979$

.02364

Share Age Group 5

.05995

.03223

.03373

.03381

Share Age Group 6

$-.08456$

.03165

Share Age Group 7

$-.02643$

.02474 
Distribution of Housing Units by Type of Structures (I unit detacted is the omitted category) Share 1 Unit Attached

$-.04477$

$-.00883$

$-.03793$

.00334

.02049

Share 5 or more Units

Share Mobile Homes

Distribution of Housing Units by Occupancy Status (Owner Occupied is the omitted category)

Share Rental

.04073

.11983

.01354

Changes in Housing Characteristics, 1980-90

Change in Total Housing Units, $1980-90$.

Change in 1-4 Family Housing Units, 1980-90

Change in Share Rental, 1980-90

Change in Share Vacant, 1980-90

Age Distribution of Housing Units, 1980 (Built before 1949 is the omitted category) Share Built 1979-80

Share Built 1975-78

Share Built 1970-74

Share Built 1960-69

Share Built 1950-59

Share Built 1940-49
$.00472 \quad .00280$

$-.00507 \quad .00290$

$.00979 \quad .01090$

$-.02661 \quad .01595$

$-.02335$

$-.00962$

.01481

$-.01246$

$-.02131$

$-.02326$
.01171

.00736

.00640

.00517

.00525

.00809 